\title{
Digital soil mapping for fire prediction and management in rangelands
}

\author{
Matthew R. Levi ${ }^{*}$ (D) and Brandon T. Bestelmeyer
}

\begin{abstract}
Background: Soil properties have important effects on fire occurrence and spread, but soils are often overlooked in fire prediction models. Quantifying soil-fire linkages is limited by information in conventional soil maps, but digital soil mapping products (e.g., detailed soil property maps) could improve both wildfire prediction models and post-fire management decisions.

Results: Of our estimated $3.7 \mathrm{Mkm}^{2}$ of rangeland in the continental US and Alaska, an average of $38000 \mathrm{~km}^{2}$ burned per year between 2008 and 2017. To highlight the role of soils in fire ecology, we present 1) a conceptual framework explaining why soil information can be useful for fire models, 2) a comprehensive suite of literature examples that used soil property information in traditional soil survey for predicting wildfire, and 3) specific examples of how more detailed soil information can be applied for pre- and post-fire decisions.
\end{abstract}

Conclusions: Digital soil mapping can improve fire prediction models and inform post-fire management decisions.

Keywords: digital soil mapping, fire effects, grasslands, shrublands, soil moisture, spatial modeling, wildfire

\section{Resumen}

Antecedentes: Las propiedades del suelo tienen efectos importantes en la ocurrencia y propagación de incendios, aunque los suelos son frecuentemente pasados por alto en los modelos de predicción de incendios. La cuantificación de los vínculos entre suelo y fuegos está limitada por la información contenida en mapas de suelos convencionales, aunque los productos de mapas de suelo digitales (i.e., mapas detallados de propiedades del suelo) pueden mejorar tanto la predicción de incendios como las decisiones de manejo post-fuego.

Resultados: De nuestras estimaciones de $3,7 \mathrm{Mkm}^{2}$ de pastizales naturales en la parte continental de EEUU y Alaska, un promedio de $38000 \mathrm{~km}^{2}$ se quemaron por año entre 2008 y 2017. Para resaltar el rol de los suelos en la ecología del fuego, presentamos 1) un marco conceptual explicando por qué la información sobre el suelo puede ser útil para modelos de incendios, 2) un conjunto comprensivo de ejemplos de la literatura que usan información sobre las propiedades del suelo en relevamientos de suelo tradicionales para predecir incendios, y 3) ejemplos específicos de cómo una información de suelos más detallada puede aplicarse para tomar decisiones pre- y post- fuegos.

Conclusiones: Los mapas de suelo digitales pueden mejorar los modelos de predicción de incendios e informar sobre decisiones de manejo post-fuego.

\footnotetext{
* Correspondence: matthew.levi@uga.edu

USDA-ARS Jornada Experimental Range, New Mexico State University, MSC

3JER, Box 30003, Las Cruces, New Mexico 88003, USA
} 


\section{Abbreviations}

DSM: Digital Soil Map

GRACE: NASA's Gravity Recovery and Climate Experiment gSSURGO: gridded SSURGO

HWSD: Harmonized World Soil Database

MTBS: Monitoring Trends in Burn Severity database NASA: National Aeronautics and Space Administration NRCS: USDA Natural Resources Conservation Service SMAP: NASA's Soil Moisture Active Passive mission SMOS: European Space Agency's Soil Moisture and Ocean Salinity mission

SSURGO: Soil Survey Geographic Database

STATSGO2: Digital General Soil Map of the United States

\section{Introduction}

Wildfire affects an estimated $148.8 \mathrm{Mkm}^{2}$ globally each year (van der Werf et al. 2017), with a recent increase of burned area in rangelands associated with increasing population density (Bistinas et al. 2013). The expanding wildland-urban interface underscores the need to provide fire risk maps to protect life and property. In the US between 2008 and 2017, an average of $38000 \mathrm{~km}^{2}$ burned in wildland and prescribed fires annually, with nearly $67000 \mathrm{~km}^{2}$ burned in 2017 alone (NIFC [National Interagency Fire Center] 2018). Rangeland extent in the US has been estimated to be between $2.4 \mathrm{Mkm}^{2}$ and $3.1 \mathrm{Mkm}^{2}$ (Joyce 1989; Reeves 2011). We derived a spatial representation of rangeland from the $2011 \mathrm{Na}$ tional Land Cover Dataset (Homer et al. 2015) to allow comparisons with wildfire data from the Monitoring Trends in Burn Severity dataset (http://mtbs.gov/direct-download). Based on the definition of rangeland as a natural ecosystem composed of predominantly grasses, forbs, or shrubs (https://globalrangelands.org/glossary), we combined shrubland and herbaceous classes (excluding pasture) and estimated an area of $3.7 \mathrm{Mkm}^{2}$ of rangeland in the continental US and Alaska (Fig. 1). Between 1984 and 2015, $326166 \mathrm{~km}^{2}$ of rangeland burned

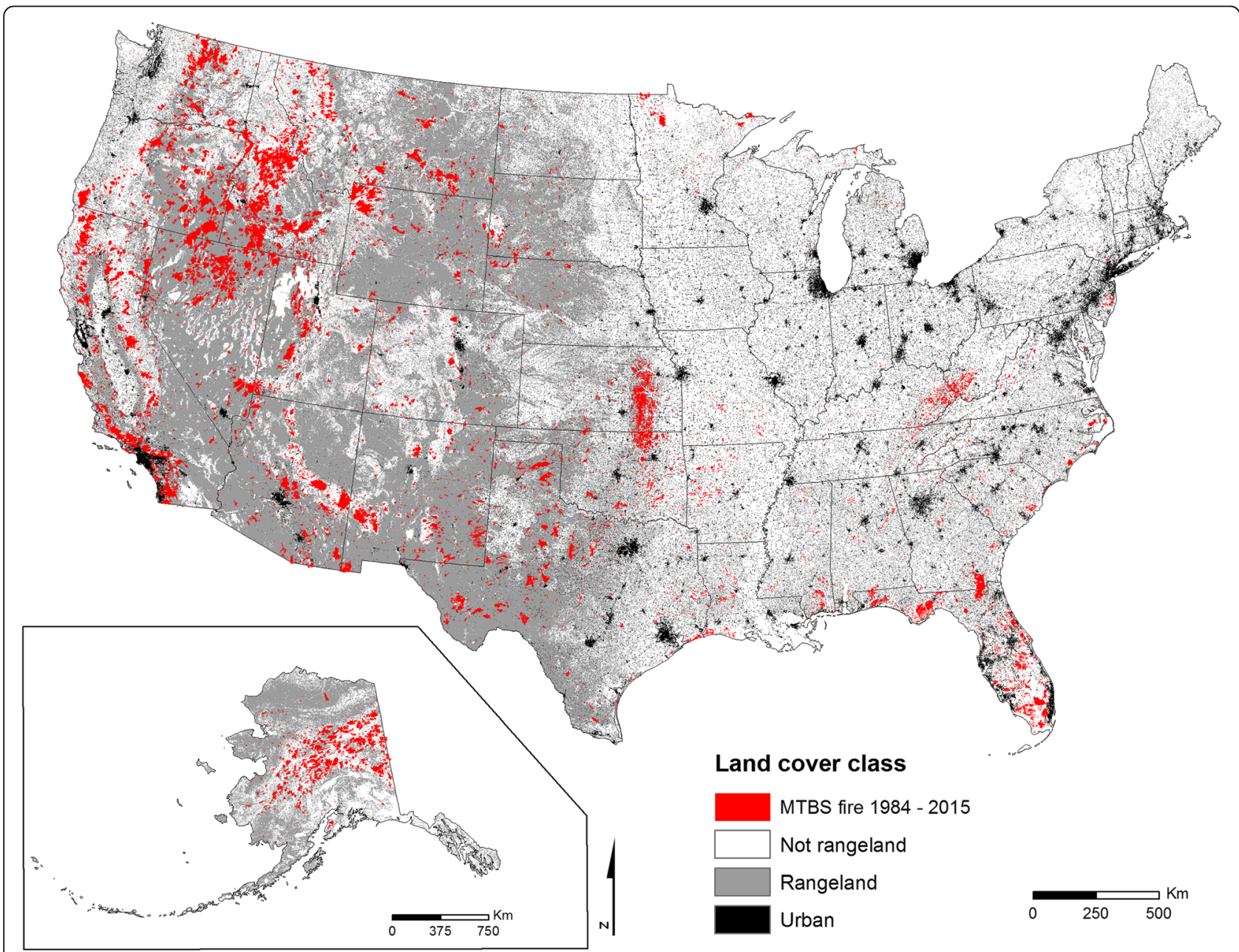

Fig. 1 Areas of the United States burned at least once by large fires between 1984 and 2015. Rangeland extent was derived from the 2011 National Land Cover Dataset (Homer et al. 2015) by combining shrubland and herbaceous classes, and urban extent represents an aggregate of all developed classes. Large fire criteria defined by MTBS standards of >405 ha in western states and >202 ha in eastern states 
at least once in large fires with an observable increase in burned area per year for the same time period (Figs. 1 and 2).

In the western US, there is considerable concern regarding the increased negative effects of fire on plant invasions and erosion (see 2011 special issue of Rangeland Ecology and Management 64[5]: 429-478). Modified fire regimes resulting from the proliferation of invasive species can lead to increased fire likelihood, putting more landscapes at risk of soil erosion (Brooks 2006). Fire effects on soil properties are strongly influenced by burn severity, which often varies significantly in space (Moody et al. 2013). Interestingly, burn severity does not always align with the fuel load (Stoof et al. 2013). This can create complex patterns of site susceptibility to hydrophobicity, erosion, and subsequent hydrologic responses (Williams et al. 2014)

Multiscale processes control fire occurrence and long-term fire regimes (Allen 2007; Falk et al. 2011). The most common variables used to model and predict fire occurrence are derived from topography, precipitation, and vegetation condition because of their relationships with fuel conditions (Littell et al. 2009; Abatzoglou 2013). These are often complemented by other properties related to fire ignition such as distance to road and lightning strike density (Yang et al. 2015). Most variables included in fire prediction models attempt to represent the necessary elements of fire occurrence: available fuel, favorable conditions for burning, and some ignition source (Krawchuk 2011).

Soil properties are frequently absent from fire prediction models (Brooks 2006; Littell et al. 2009; Hawbaker et al. 2013; Gray and Dickson 2014), although some recent studies have begun to utilize soil information such as soil moisture to predict fire occurrence. For example, Krueger

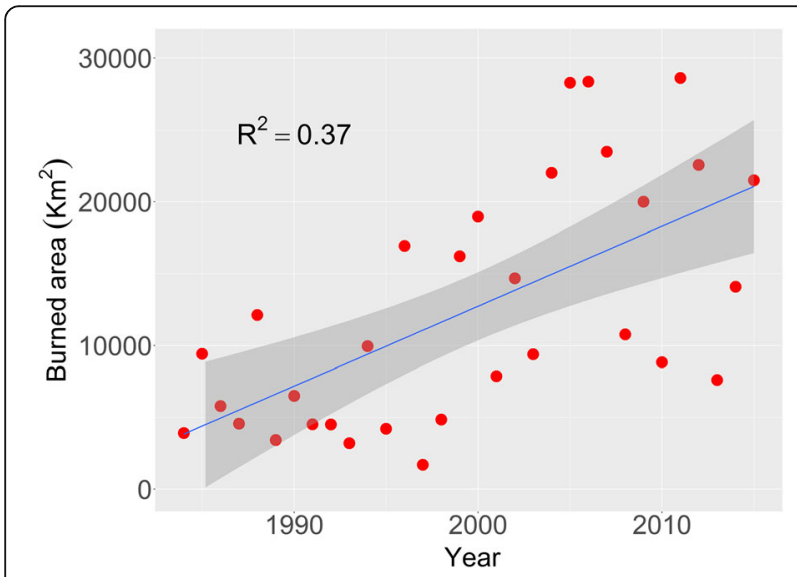

Fig. 2 Area of burned rangeland in the United States by large fires from 1984 and 2015. Shaded area represents the 95\% confidence interval. Large fire criteria and rangeland delineations are described in Fig. 1 et al. (2015) found that measured soil moisture strongly influences wildfire activity during much of the year in Oklahoma, USA, because it influences plant productivity and live fuel moisture directly. Soil moisture has also been shown to be a better predictor of the occurrence of large growing-season wildfires than the commonly used Keetch-Byram drought index (Krueger et al. 2017). Remotely sensed soil moisture has also been used recently to predict wildfire occurrence across the contiguous US (Jensen et al. 2018). Integrating bottom-up (e.g., soil, topography) and top-down (e.g., precipitation, temperature) controls of wildfire is necessary for refining local models of fire susceptibility and improving our ability to produce fire risk assessments in a rapidly changing climate.

In addition to fire prediction models, soil properties are especially important for managing soil landscapes post fire because fire behavior directly influences soil conditions that interact with flora, fauna, and landscapes to impact processes such as runoff and erosion (Hyde et al. 2013). In contrast to wildfire predictions, soil information is commonly included in post-fire management and modeling. Even though soil is recognized as an important element of post-fire management, there is still an imperative need to better quantify the interactions between fire severity and hydraulic soil properties across a wide range of spatial scales (Moody et al. 2013). Many wildland fires happen in remote areas where on-the-ground inventories of soil, vegetation, and burn severity have been inhibited by cost, time, or logistics. Optimizing available resources for pre-and post-fire applications requires the integration of a comprehensive suite of environmental data.

Fire is a natural process in many rangeland systems, and being able to predict when and where on the landscape it will occur continues to be a critical need (Rangeland Fire Task Force 2015). Post-fire management decisions also become more important as larger areas experience fire, putting more areas at risk for soil erosion and subsequent degradation and water quality issues (Fig. 2). We believe that both pre- and post-fire management decisions could benefit from more applied uses of existing and newly generated soil maps. The goals of this paper are to illustrate the importance of including soil property information in fire prediction models and post-fire response, describe map-based soil information that is currently available, and discuss the potential for digital soil mapping to improve pre- and post-fire management decisions in rangelands.

\section{Linking fire to soil properties}

The vast majority of research related to fire and soil properties is focused on the effect of fire on soil properties (Massman and Frank 2010; Sankey et al. 2012a; Moody et al. 2013; Alcaniz et al. 2018); however, the 
interaction of soil properties and precipitation is an important predictor of vegetation condition and live fuel moisture that is difficult to quantify and consequently not emphasized in models of fire prediction. Vegetation condition is well recognized as an important factor in modeling fire occurrence because it has the most direct influence on the likelihood of burning and subsequent fire characteristics (size, severity, etc.). It is well recognized that climate-driven thermal and moisture gradients control fire regimes at coarse and intermediate scales (Whitman et al. 2015), but resolving fire behavior at finer spatial and temporal scales requires information including current vegetation condition, live fuel moisture, and relative humidity, all of which are affected strongly by soil properties. Conceptual models of fire likelihood often connect soil moisture conditions to the resource gradient of physical conditions (Krawchuk 2011; McWethy et al. 2013); however, soil moisture remains a difficult property to quantify with fine spatial and temporal detail over large areas (Ochsner et al. 2013). For example, satellite remote sensing missions dedicated to soil moisture monitoring provide global coverage but generally have coarse spatial resolution and only predict conditions for the top several centimeters of soil (Ochsner et al. 2013; Jensen et al. 2018). In contrast to the top-down control of climate-space data on fire conditions, soil moisture dynamics and other soil property influences represent a bottom-up mechanism (Fig. 3).
Management activities interact with both fine- and coarse-scale drivers to produce a complex mix of possible scenarios in any given environment. Furthermore, there is strong evidence for variable contributions of bottom-up controls in different types of fire-prone landscapes (Krawchuk 2011; Parks and Parisien 2012). Integrating all of these drivers is a complicated, albeit necessary, task to refine fire prediction models and develop better predictive ability for post-fire recovery.

Soil-vegetation relationships and subsequent fire distribution vary with climate. This can be discussed in the context of a resource-limited system compared to one with ample biomass (Krawchuk 2011). For example, in semiarid rangelands, soil moisture exerts strong control on site characteristics such as vegetation community structure as well as current conditions of fire susceptibility like fuel load and moisture status. In very cold rangeland systems where permafrost controls soil drainage (e.g., Alaskan tundra), temperature can influence effective soil depth and subsequent soil moisture conditions. Spatial and temporal soil moisture conditions are also affected by a suite of soil properties including texture, rock fragments, and organic matter. Therefore, long-term projections of fire likelihood can be tied to soil types or key properties affecting soil moisture. The interaction of soil with climate is an important element of both short- and long-term projections of fire.

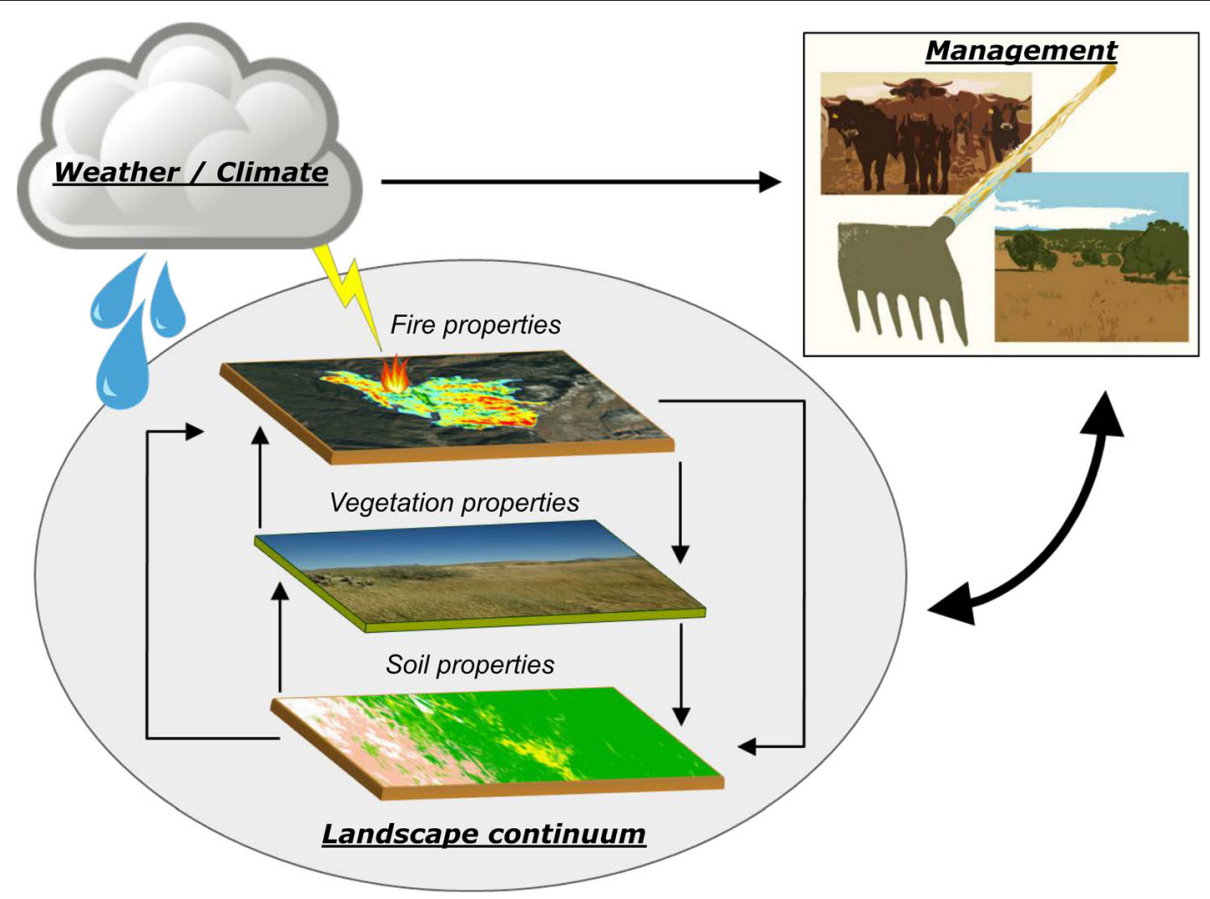

Fig. 3 Conceptual soil-fire linkages with vegetation and overarching influence of weather, climate, and management. Weather and long-term climate are macro-scale drivers with minimal feedback from the landscape continuum, whereas management has a more balanced linkage with the landscape and also direct influence from weather 


\section{Available soil information and fire modeling examples}

Options for deriving soil information relevant for fire modeling include an assortment of conventional soil maps, digital soil maps, and proxy measurements of soil properties like soil moisture (Table 1). Grunwald and Thompson (2011) provide a concise summary of common global, national, and regional soil datasets available in a digital format, and the International Soil Reference and Information Centre (ISRIC) provides a comprehensive list of soil geographic databases from across the world (ISRIC [International Soil Reference and Information Centre] 2018). A wide range of soil properties influence the type, amount, and moisture content of fuels as well as the trajectories of recovery in areas following a burn. Soil moisture is arguably the most important soil property for fire prediction because of the tight coupling with fuel moisture (Qi et al. 2012; Krueger et al. 2015). The antecedent soil moisture conditions are especially important for predicting likely fire risk due to the influence on fuel accumulation (Krawchuk 2011; Gray and Dickson 2014). Properties that control soil moisture conditions and potential water holding capacity of a soil, like soil texture and the amount of rock fragments, are also very important for predicting soil moisture conditions. For post-fire applications, properties that influence erodibility, hydrophobicity, aggregation, and nutrient content are very important for the recovery of a given landscape after burning. Erosion models are frequently used to assess risks following fire and typically require soil inputs like texture and rock fragments (Miller et al. 2016). For plant recovery following fire, things such as soil fertility, hydrophobicity, soil moisture, and rates of erosion are important factors.

\section{Conventional soil mapping}

Conventional soil maps provide information about soil properties that relate to soil genesis, morphology, and classification using polygons for spatial representation (Soil Science Division Staff 2017). The mapping scale is generally dependent upon the specific management goals of the project. Soil data available are usually representative values of named soil types, which are aggregated for spatial representation in polygons. This results in soil map units that can have coarse representation of soil property variability within the polygon. A variety of conventional soil maps have been compiled as the Harmonized World Soil Database (HWSD; Table 1) to provide global coverage (Wieder et al. 2014). These polygonbased maps of global extent generally have coarse spatial resolution and somewhat generalized attribute information due to limitations of mapping such large areas. Many regional soil maps cover individual countries at various resolution and detail. In the US, there are three main soil products including the Digital General Soil Map of the United States (STATSGO2; Soil Survey Staff 2018c), Soil Survey Geographic Database (SSURGO; Soil Survey Staff 2018b), and gridded SSURGO (gSSURGO; Soil Survey Staff 2018a) (Table 1). These provide more detailed information than global datasets, with estimated soil properties and interpretations for land management (Soil Science Division Staff 2017). While these maps are produced by expert soil scientists, there are limitations on the quantification of soil property variability and spatial distribution across the landscape.

A major benefit of soil survey information is the variety of interpretations connected to soil map units. For example, SSURGO provides a rating of potential damage by fire that reflects the susceptibility of nutrient, physical, and biotic soil properties to fire (e.g., Fig. 4). This interpretation is a useful tool for prioritizing resources for both preventative management and post-fire assessment (e.g., Burned Area Emergency Rehabilitation). In addition, soil map units are linked to ecological site classifications, which describe soil- and climate-related variations in potential vegetation and its responses to natural and anthropogenic drivers (Moseley et al. 2010). Ecological sites commonly incorporate fire into "state and transition models," which describe the causes of ecological state change (e.g., large shifts in plant communities) alongside recommendations to manage state change in desired ways (Bestelmeyer et al. 2010). Recommendations associated with fire management may include fire frequencies needed to sustain or alter a given plant community and seed mixes or erosion control strategies to accelerate post-fire recovery. State and transition models can also be used to scale up ecological site information into disturbance response groups that may facilitate post-fire rehabilitation following large fires (Stringham et al. 2016). For rangeland landscapes that are at risk of transitioning to communities dominated by non-native, invasive plants, state and transition models provide valuable site-specific predictions regarding changes in and management of vegetation in the face of changing fire regimes.

Some studies have used static soil properties from conventional soil maps to model wildfires. Levi (2016) found soil water holding capacity and ecological sites to be useful for explaining fire occurrence in desert grasslands of the southwestern US. Dilts and Sibold (2009) explored the use of soil water holding capacity and infiltration rate to model fire, but found insignificant effects and removed the variable from subsequent models, likely a reflection of the coarse-scaled soil information that they derived from the STATSGO2 database. Coarse resolution of soil inputs have also been identified as a limitation for fire prediction models in northern Wisconsin, where Sturtevant (2007) used STATSGO2 to derive soil 


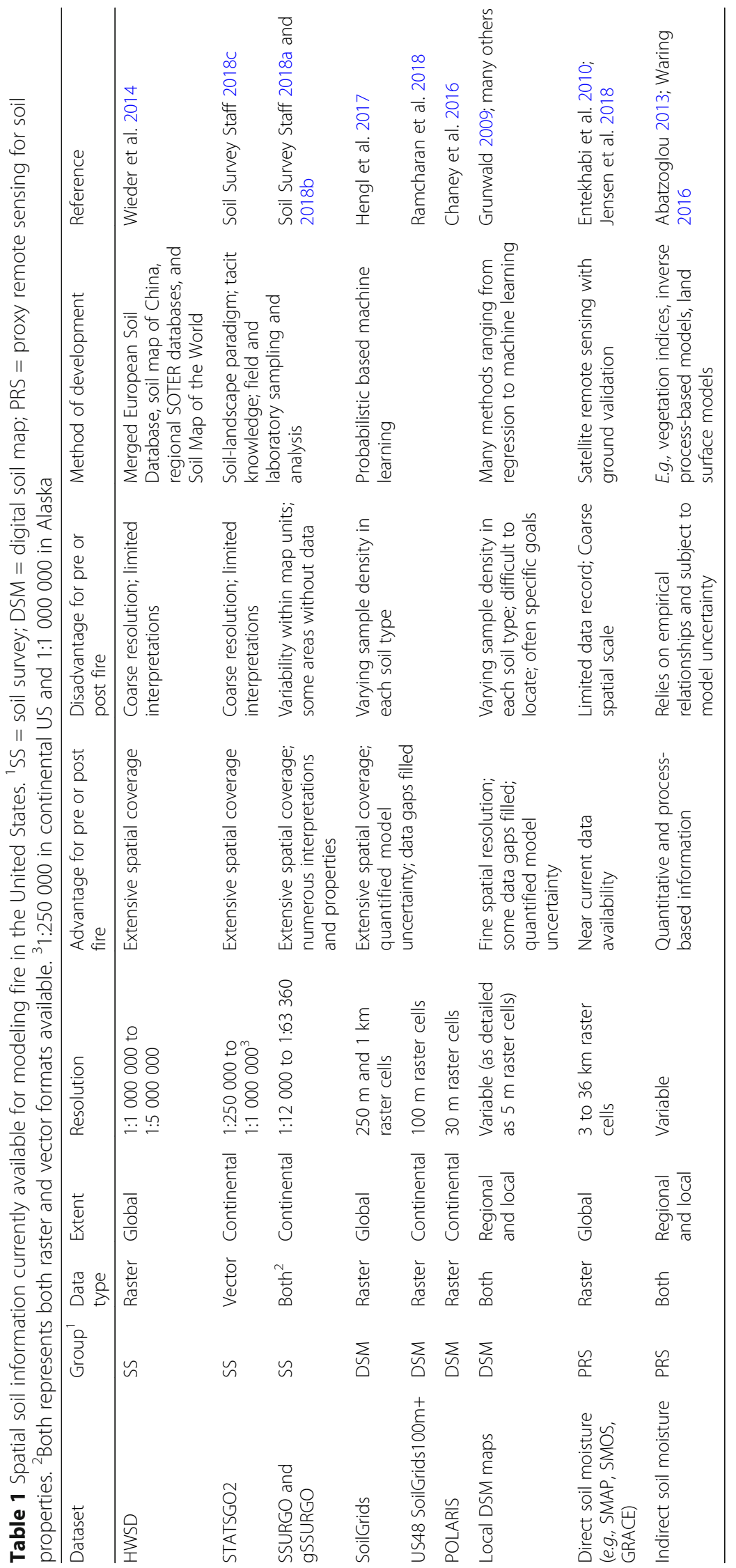



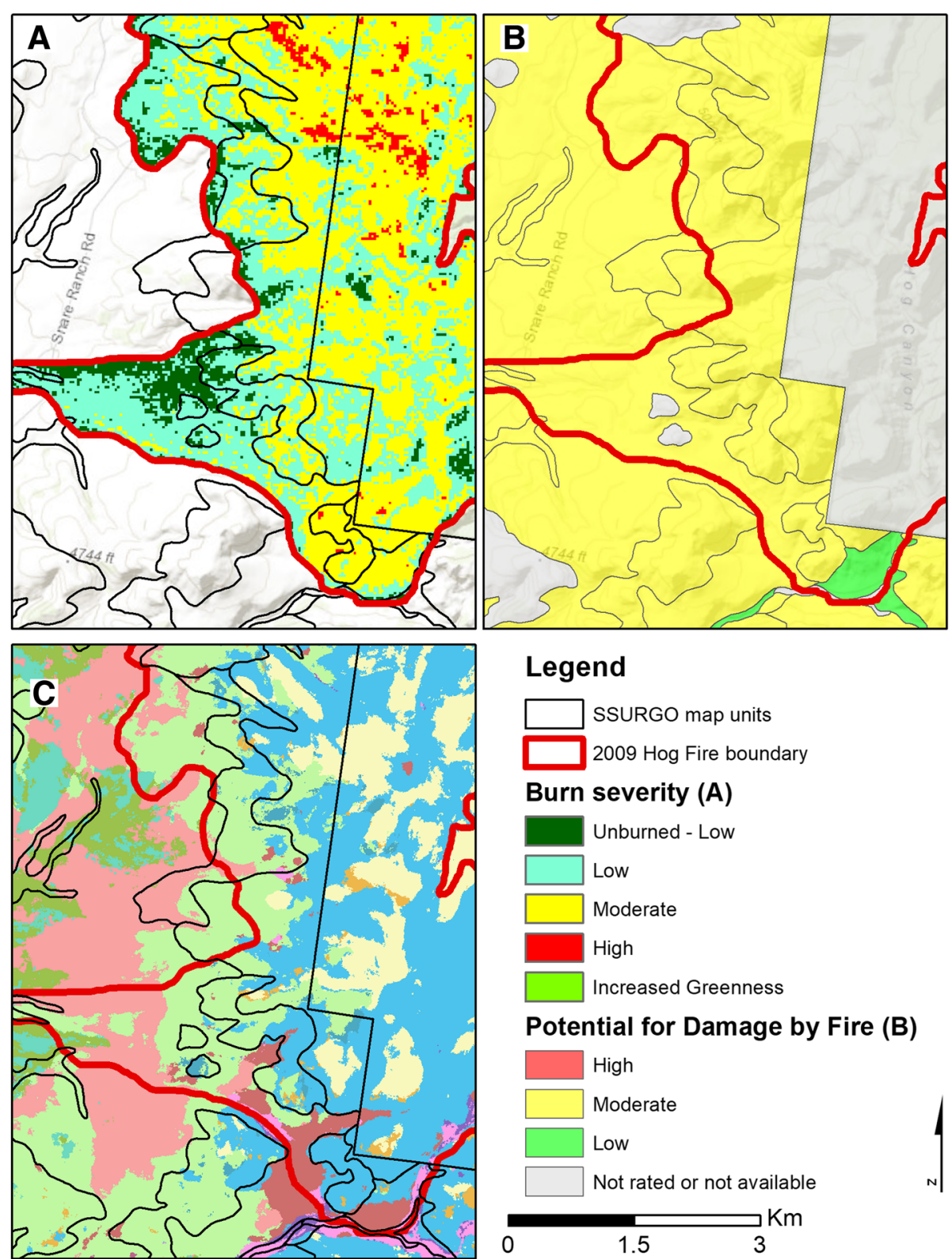

Fig. 4 Fire severity map for the 2009 Hog Fire in southeastern Arizona, USA (about 45 km northeast of Douglas, in the Peloncillo Mountains), derived from the MTBS project with available SSURGO soil map component boundaries (a), potential damage from fire interpretation from SSURGO (b), and a digital soil map of predicted soil components (c; Levi 2017; each color in panel C represents a different soil component). Integration of soil property maps with burn severity is critical for modeling post-fire erosion. Approximately half of the Hog Fire burned on national forest land with no published soil survey available, but the digital soil map provides predicted soil components for the full extent of the burned area. For direct comparison of soil components from digital soil mapping and SSURGO presented in panel c, please see figure 4 in Levi 2017

water holding capacity, drainage class, and hydric soil ratings. Harden et al. (2001) used a simple metric of soil drainage integrated from soil water holding capacity, infiltration rate, and hydraulic conductivity to characterize the state of Alaska, and then related that to wildfire. They determined that more poorly drained areas had more fire activity than better drained areas. However, they used the STATSGO2 database, and soil map units were about six times larger than the fire polygons, which only allowed for relatively simple statistical analyses. We suggest that using soil information that is better matched to the scale of interest for a particular fire modeling application could be more informative. For example, the above studies may have had better relationships between fire predictions and soil properties if they had used more detailed SSURGO data or a suite of digital soil mapping products. 


\section{Digital soil mapping}

Digital soil mapping is an approach for predicting soil properties or soil types by incorporating measured soil properties at known point locations with environmental covariate layers having continuous spatial coverage (e.g., Landsat satellite data, digital elevation models; McBratney and Santos 2003, Scull et al. 2003). These soil prediction models can utilize simple regression or complex machine learning and generally provide improved estimates of soil properties at a finer spatial scale than currently available soil map products. A tremendous benefit of digital soil mapping models is the ability to produce some measure of model accuracy or confidence that can be incorporated into subsequent models. Digital soil mapping is generally used to predict static soil properties, but these properties can be incorporated with other models to derive more dynamic soil properties.

Digital soil mapping is a practical solution for refining the spatial variability of soil information for large areas. A variety of digital soil maps are currently available including global (SoilGrids; Hengl et al. 2017) and regional (e.g., POLARIS; Chaney et al. 2016) products (Table 1). SoilGrids is a global product of soil property information available in a raster data format with $250 \mathrm{~m}$ resolution (Hengl et al. 2017), with recent advances for the continental US that provide data for $100 \mathrm{~m}$ pixels (Ramcharan et al. 2018). There are also local scale examples of digital soil mapping that could be useful for fire modeling. For example, the 2009 Hog Fire burned $73 \mathrm{~km}^{2}$ in southeastern Arizona, USA, where approximately half of the burned area occurred on national forest land with no published soil survey available (Fig. 4). However, a digital soil map is available from work by Levi (2017) and provides predicted soil components for most of the burned area. A simple intersection of the digital soil map and the Hog Fire boundary indicated that two soil components accounted for $79 \%$ of the burned area. One drawback of digital soil mapping data for fire modeling is that knowing about and then accessing localized data may be difficult as there is not currently a clearinghouse or repository of these data. Some review papers offer one mechanism of identifying existing studies (e.g., Grunwald 2009) and the USDA Natural Resources Conservation Service (NRCS) has compiled an annotated bibliography of digital soil mapping projects with NRCS participation (see NRCS 2018), but such lists are often not comprehensive. Some larger-scale projects like the $100 \mathrm{~m}$ SoilGrids project are readily available (Table 1). Another challenge to utilizing previously developed digital soil maps is that project objectives may have produced soil property maps that would not be easily translated to relevant fire ecology questions.

\section{Soil moisture mapping}

Perhaps the greatest potential for better incorporating soil information into fire modeling is through soil moisture. Soil moisture conditions are tied closely to live fuel moisture content, which is a critical element of wildfire risk models (Qi et al. 2012). The spatial coverage of in situ soil moisture measurements represents only a very small fraction of the landscapes on which wildfires most commonly occur. Efforts to compile these measured data, such as the North American Soil Moisture Database (Quiring et al. 2016), present more opportunities for utilizing soil moisture measurements in fire research. Advancements in soil moisture modeling also provide much needed information for incorporating into an assortment of applications, including fire modeling. A variety of methods exist to predict soil moisture for large spatial areas including cosmic-ray neutron radiation, indirect Global Positioning System signals, remotely sensed land surface temperature measurements, and remote sensing missions specifically designed to measure soil moisture (Ochsner et al. 2013). In recent years, remotely sensed soil moisture data has been used to model fire activity for large areas using several platforms including the European Space Agency's Soil Moisture and Ocean Salinity mission (SMOS; Chaparro et al. 2016) and National Aeronautics and Space Administration's (NASA) Gravity Recovery and Climate Experiment (GRACE; Jensen et al. 2018). NASA's Soil Moisture Active Passive (SMAP) mission also has tremendous potential for providing valuable soil moisture datasets that could be applied to fire prediction models (Entekhabi et al. 2010). Remote sensing missions may offer the greatest potential to inform pre- and post-fire applications for large areas; however, the coarse spatial resolution remains a limitation for landscape scales (Jensen et al. 2018).

In lieu of directly mapping soil moisture, another approach is to use models for predicting soil moisture conditions. For example, Abatzoglou (2013) used a land surface model to derive soil moisture for predicting area burned across the western US. Coops and Waring (2012) derived soil fertility and available soil water holding capacity for forested areas in a large area of western North America by inverting a forest growth model adjusted with remotely sensed leaf area index. Krawchuk (2011) used modeled soil moisture to explore the influence of global resource gradients on fire distribution, and Waring (2016) used soil water balance to model large wildfires across the western US. These proxy measurements of soil properties can be useful for interpreting factors such as soil moisture, leaf area index, and fuel moisture using remote sensing that can also aid in prediction of pre- and post-fire processes. 


\section{How digital soil mapping can improve fire management Fire danger systems}

The most immediate benefit of having detailed soil information prior to fire occurrence is the potential for refining fire prediction models of occurrence and burn severity. Improved soil information with spatially explicit estimates of model confidence can allow utilization of more quantitative fire-soil relationships in fire danger systems. Soil moisture models that require physical soil properties for accurate representation of spatiotemporal soil moisture conditions will also benefit the fire modeling community by providing more robust inputs for $d y-$ namic fire risk assessment.

Creative applications of these data can facilitate the development of new prediction tools. For example, derivatives of soil moisture related to the fraction of available soil water can be more useful for predicting fire occurrence than actual soil moisture (Krueger et al. 2015, Waring 2016). Incorporating antecedent conditions of soil moisture (Krawchuk 2011) can be refined with more detailed soil property information resulting from digital soil mapping. Applying these drought index concepts specifically to soil moisture conditions and how that relates to the potential of the soil to hold water requires better constraints on soil properties than currently available with conventional soil maps.

\section{Fire ecology}

Interpreting complex relationships between soil, vegetation, climate, and management, and the subsequent feedbacks with fire requires spatially explicit information. As we continue to refine our understanding of fire-prone environments and predict the impacts of changing climate and management, there is an increasing need to quantify all factors involved. Conventional soil maps provide valuable information; however, the scale of soil mapping in many forest and rangeland landscapes limits our ability to derive site-specific relationships necessary for advancing the science of fire ecology. Digital soil mapping techniques present an opportunity to better quantify the relationships between soil and fire, which has largely been unexplored.

Digital soil maps can potentially unlock interdisciplinary scientific questions related to fire ecology. For example, a recent study in Alaska used digital soil mapping to predict soil moisture and interpret fire severity. The authors estimated that $90 \%$ of the high-severity fire zone lacked permafrost after fire (Brown et al. 2016). Recent changes in the climate of northern latitudes have heightened concern regarding the melting of permafrost and subsequent effects on carbon dynamics and wildfire susceptibility; soil properties play a major role in these processes. A second example of applying digital soil maps could quantify the restoration trajectories of burned areas or design research studies to further investigate fire effects. For example, Nauman and Duniway (2016) developed a detailed soil map of particle size in the soil profile to identify matching soil-geomorphic sites on the Colorado Plateau, USA. They later combined the soil prediction map with other remote sensing data to evaluate the ecological recovery of disturbed sites following oil and gas extraction (Nauman et al. 2017). This same process could be applied to identify similar soil-geomorphic zones for monitoring and comparing burned and unburned areas.

We know that soils interact with climate, vegetation, and management to control the trajectory of post-fire recovery rates for a given landscape. The first-order effects of fire on soil are related to the changes that happen when soil is heated (Massman and Frank 2010), and the degree of alteration for different soil properties is directly related to soil temperatures reached during a fire (Alcaniz et al. 2018); thus, conditions at the time of fire determine the effect of a fire on the soil. Soil heating is also a major factor controlling the recovery of plants following fire because of the effects on existing vegetation and seed bank (Stephan and Miller 2010; Smith and Abella 2014). Dynamic soil properties like soil moisture and organic matter content interact with static soil properties (e.g., texture, pore space) resulting in varying degrees of heat transfer and soil alteration that vary across spatial and temporal scales (Moody et al. 2013). Detailed knowledge of soil conditions, such as those obtained from digital soil mapping, can enable more quantitative interpretations of soil-fire interactions than are currently available with existing soil information.

\section{Soil erosion models}

It is well accepted that fire can adversely affect surface soil properties and alter the spatial patterns of soil resources (Allen and Steers 2011, Sankey et al. 2012a, Sankey et al. 2012b). This is important for predicting erosion and revegetation, but conducting post-fire surveys of soil conditions are expensive and often challenging to complete in a timely manner. It is typical to utilize soil surveys to obtain properties related to erosion and revegetation potential and other characteristics (US National Park Service 2006). Soil maps are thus a critical component for post-fire planning and assessment. For example, soil burn severity assessments are commonly linked with existing models that predict post-fire hydrology and erosion using soil property information (Parsons et al. 2010). Numerous models have been used to predict erosion and debris flow following fire including WEPP (Laflen et al. 1997), GeoWEPP (Renschler 2003), ERMiT (Robichaud et al. 2007), and Ravel RAT (Fu 2004), all of which require soil property inputs (Miller et al. 2016). In most cases, conventional soil maps like STATSGO2 and 
SSURGO are used to derive these inputs; however, digital soil maps can provide more detailed information with spatially explicit representations of model confidence that can subsequently be incorporated into landscape models.

Digital soil mapping can also provide soil information in areas for which conventional soil maps are currently unavailable (e.g., national forests; Fig. 4). One of the largest areas in the US lacking detailed soil survey information (i.e., SSURGO) is Alaska, which has approximately $801000 \mathrm{~km}^{2}$ of rangeland (Fig. 1). Better soils information means better potential to model soil erosion and watershed effects following fire. Understanding the relationships between burn severity and soil properties is an exceptionally high priority for post-wildfire runoff and erosion research (Moody et al. 2013). There is a great need to have a quantitative data set of important soil information (among other data) to facilitate rapid modeling in response to fire (Miller et al. 2016).

\section{Concluding remarks}

Advances in soil modeling offer solutions for resolving the scarcity of relevant soil property information necessary for improving fire modeling. Observed trends in the burned area of US rangelands underscore the need to improve fire danger systems in these areas. There are clear contributions of soil properties to fire occurrence that are not fully being utilized by the fire modeling community. Soil properties are commonly assessed and used to predict erosion and landscape recovery after fire because they strongly influence these responses in burned areas. We believe that soil maps and other soil property information have the potential to advance our ability to predict fire likelihood and model watershed-scale processes for areas after they burn. Digital soil mapping presents an opportunity to advance our understanding of soil-fire relationships by providing detailed soil information necessary for site-specific interpretations. Applying more quantitative soil information to fire science will provide more tools for both pre- and post-fire management decisions, which translate to more effective and efficient use of resources for mitigating negative effects in burned areas.

\section{Acknowledgements}

We would like to acknowledge the comments of two anonymous reviewers who provided valuable comments for the final version of this manuscript.

\section{Funding}

This work was supported by the USDA ARS Postdoctoral Research Associate Program.

\section{Availability of data and materials}

The datasets generated or analyzed during this study are available in the following repositories: Monitoring Trends in Burn Severity repository http:// mtbs.gov/direct-download, the National Land Cover Dataset repository https://www.mrlc.gov/nlcd2011.php, and the Jornada Spatial Data Catalog https://jornada.nmsu.edu/data-catalogs/spatial, or otherwise available from the corresponding author on reasonable request.

\section{Authors' contributions}

MRL initiated analysis, processed data, performed data analysis, and created figures. BTB guided analyses and overarching focus. Both authors wrote the paper, interpreted data, developed figures, edited the manuscript, and have given final approval of the version to be published.

Ethics approval and consent to participate

Not applicable.

\section{Consent for publication}

Not applicable.

Competing interests

The authors declare that they have no competing interests.

\section{Publisher's Note}

Springer Nature remains neutral with regard to jurisdictional claims in published maps and institutional affiliations.

Received: 15 October 2018 Accepted: 25 October 2018

Published online: 27 December 2018

\section{References}

Abatzoglou, J.T., and C.A. Kolden. 2013. Relationships between climate and macroscale area burned in the western United States. International Journal of Wildland Fire 22: 1003-1020 https://doi.org/10.1071/WF13019.

Alcaniz, M., L. Outeiro, M. Francos, and X. Ubeda. 2018. Effects of prescribed fires on soil properties: A review. The Science of the Total Environment 613: 944957 https://doi.org/10.1016/.sscitotenv.2017.09.144.

Allen, C.D. 2007. Interactions across spatial scales among forest dieback, fire, and erosion in northern New Mexico landscapes. Ecosystems 10: 797-808 https:// doi.org/10.1007/s10021-007-9057-4.

Allen, E.B., R.J. Steers, and S.J. Dickens. 2011. Impacts of fire and invasive species on desert soil ecology. Rangeland Ecology \& Management 64: 450-462 https://doi.org/10.2111/rem-d-09-00159.1.

Bestelmeyer, B.T., K. Moseley, P.L. Shaver, H. Sanchez, D.D. Briske, and M.E. Fernandez-Gimenez. 2010. Practical guidance for developing state-andtransition models. Rangelands 32: 23-30 https://doi.org/10.2111/ RANGELANDS-D-10-00077.1.

Bistinas, I., D. Oom, A.C.L. Sá, S.P. Harrison, I.C. Prentice, and J.M.C. Pereira. 2013. Relationships between human population density and burned area at continental and global scales. PLoS One 8: e81188 https://doi.org/10.1371/ journal.pone.0081188.

Brooks, M.L., and J.R. Matchett. 2006. Spatial and temporal patterns of wildfires in the Mojave Desert, 1980-2004. Journal of Arid Environments 67: 148-164 https://doi.org/10.1016/j.jaridenv.2006.09.027.

Brown, D.R.N., M.T. Jorgenson, K. Kielland, D.L. Verbyla, A. Prakash, and J.C. Koch 2016. Landscape effects of wildfire on permafrost distribution in interior Alaska derived from remote sensing. Remote Sensing 8: 22 https://doi.org/10. 3390/rs8080654.

Chaney, N.W., E.F. Wood, A.B. McBratney, J.W. Hempel, T.W. Nauman, C.W. Brungard, and N.P. Odgers. 2016. POLARIS: A 30-meter probabilistic soil series map of the contiguous United States. Geoderma 274: 54-67 https://doi.org/ 10.1016/j.geoderma.2016.03.025.

Chaparro, D., M. Piles, M. Vall-Llossera, and A. Camps. 2016. Surface moisture and temperature trends anticipate drought conditions linked to wildfire activity in the Iberian Peninsula. European Journal of Remote Sensing 49: 955-971 https://doi.org/10.5721/EuJRS20164950.

Coops, N.C., R.H. Waring, and T. Hilker. 2012. Prediction of soil properties using a process-based forest growth model to match satellite-derived estimates of leaf area index. Remote Sensing of Environment 126: 160-173 https://doi.org/ 10.1016/j.rse.2012.08.024.

Dilts, T.E., J.S. Sibold, and F. Biondi. 2009. A weights-of-evidence model for mapping the probability of fire occurrence in Lincoln County, Nevada. Annals of the Association of American Geographers 99: 712-727 https://doi.org/10. 1080/00045600903066540.

Entekhabi, D., E.G. Njoku, P.E. O'Neill, K.H. Kellogg, W.T. Crow, W.N. Edelstein, J.K. Entin, S.D. Goodman, T.J. Jackson, J. Johnson, J. Kimball, J.R. Piepmeier, R.D. Koster, N. Martin, K.C. McDonald, M. Moghaddam, S. Moran, R. Reichle, J.C. Shi, M.W. Spencer, S.W. Thurman, L. Tsang, and J. van Zyl. 2010. The soil 
moisture active passive (SMAP) mission. Proceedings of the IEEE 98: 704-716 https://doi.org/10.1109/jproc.2010.2043918.

Falk, D.A., E.K. Heyerdahl, P.M. Brown, C. Farris, P.Z. Fulé, D. McKenzie, T.W. Swetnam, A.H. Taylor, and M.L. Van Horne. 2011. Multi-scale controls of historical forest-fire regimes: New insights from fire-scar networks. Frontiers in Ecology and the Environment 9: 446-454 https://doi.org/10.1890/100052.

Fu, X. 2004. A physical model of dry ravel movement. Pullman: Thesis, Washington State University.

Gray, M.E., B.G. Dickson, and L.J. Zachmann. 2014. Modelling and mapping dynamic variability in large fire probability in the lower Sonoran Desert of South-Western Arizona. International Journal of Wildland Fire 23: 1108-1118 https://doi.org/10.1071/wf13115.

Grunwald, S. 2009. Multi-criteria characterization of recent digital soil mapping and modeling approaches. Geoderma 152: 195-207 https://doi.org/10.1016/j. geoderma.2009.06.003.

Grunwald, S., J.A. Thompson, and J.L. Boettinger. 2011. Digital soil mapping and modeling at continental scales: Finding solutions for global issues. Soil Science Society of America Journal 75: 1201-1213 https://doi.org/10.2136/ sssaj2011.0025.

Harden, J.W., R. Meier, C. Silapaswan, D.K. Swanson, and A.D. McGuire. 2001. Soil drainage and its potential for influencing wildfires in Alaska. In Studies by the US geological survey in Alaska, 2001, ed. J. Galloway, 139-144. Menlo Park: US Geological Survey Professional Paper 1678.

Hawbaker, T.J., V.C. Radeloff, S.I. Stewart, R.B. Hammer, N.S. Keuler, and M.K. Clayton. 2013. Human and biophysical influences on fire occurrence in the United States. Ecological Applications 23: 565-582 https://doi.org/10.1890/121816.1.

Hengl, T., J. Mendes de Jesus, G.B.M. Heuvelink, M. Ruiperez Gonzalez, M. Kilibarda, A. Blagotić, W. Shangguan, M.N. Wright, X. Geng, B. BauerMarschallinger, M.A. Guevara, R. Vargas, R.A. MacMillan, N.H. Batjes, J.G.B. Leenaars, E. Ribeiro, I. Wheeler, S. Mantel, and B. Kempen. 2017. SoilGrids250m: Global gridded soil information based on machine learning PLOS ONE 12: e0169748 https://doi.org/10.1371/journal.pone.0169748.

Homer, C.G., J. Dewitz, L. Yang, S. Jin, P. Danielson, G. Xian, J. Coulston, N. Herold, J. Wickham, and K. Megown. 2015. Completion of the 2011 National Land Cover Database for the conterminous United States-Representing a decade of land cover change information. Photogrammetric Engineering and Remote Sensing 81: 345-354.

Hyde, K., M.B. Dickinson, G. Bohrer, D. Calkin, L. Evers, J. Gilbertson-Day, T. Nicolet, K. Ryan, and C. Tague. 2013. Research and development supporting riskbased wildfire effects prediction for fuels and fire management: Status and needs. International Journal of Wildland Fire 22: 37-50 https://doi.org/10. 1071/wf11143.

ISRIC [International Soil Reference and Information Centre]. 2018. Explore ISRIC. <https://www.isric.org/explore>. Accessed 4 Sept 2018.

Jensen, D., J.T. Reager, B. Zajic, N. Rousseau, M. Rodell, and E. Hinkley. 2018. The sensitivity of US wildfire occurrence to pre-season soil moisture conditions across ecosystems. Environmental Research Letters 13: 014021 https://doi.org/ 10.1088/1748-9326/aa9853.

Joyce, L. 1989. An analysis of the range forage situation in the United States: 19892040. A technical document supporting the 1989 US Department of Agriculture, Forest Service RPA assessment, USDA Forest Service general technical report RMGTR-180. Rocky Mountain Forest and Range Experimental Station: Fort Collins.

Krawchuk, M.A., and M.A. Moritz. 2011. Constraints on global fire activity vary across a resource gradient. Ecology 92: 121-132 https://doi.org/10.1890/091843.1.

Krueger, E.S., T.E. Ochsner, D.M. Engle, J.D. Carlson, D. Twidwell, and S.D. Fuhlendorf. 2015. Soil moisture affects growing-season wildfire size in the southern Great Plains. Soil Science Society of America Journal 79: 1567-1576 https://doi.org/10.2136/sssaj2015.01.0041.

Krueger, E.S., T.E. Ochsner, S.M. Quiring, D.M. Engle, J.D. Carlson, D. Twidwell, and S.D. Fuhlendorf. 2017. Measured soil moisture is a better predictor of large growing-season wildfires than the Keetch-Byram drought index. Soil Science Society of America Journal 81: 490-502 https://doi.org/10.2136/sssaj2017.01. 0003.

Laflen, J., W. Elliot, D. Flanagan, C. Meyer, and M. Nearing. 1997. WEPP_Predicting water erosion using a process-based model. Journal of Soil and Water Conservation 52: 96-102.

Levi, M.R. 2017. Neighborhood size of training data influences soil map disaggregation. Soil Science Society of America Journal 81: 354-368 https:// doi.org/10.2136/sssaj2016.08.0258.
Levi, M.R., and B.T. Bestelmeyer. 2016. Biophysical influences on the spatial distribution of fire in the desert grassland region of the southwestern USA. Landscape Ecology 31 (9): 2079-2095 https://doi.org/10.1007/s10980-0160383-9.

Littell, J.S., D. McKenzie, D.L. Peterson, and A.L. Westerling. 2009. Climate and wildfire area burned in western US ecoprovinces, 1916-2003. Ecological Applications 19: 1003-1021 https://doi.org/10.1890/07-1183.1.

Massman, W.J., J.M. Frank, and S.J. Mooney. 2010. Advancing investigation and physical modeling of first-order fire effects on soils. Fire Ecology 6: 36-54 https://doi.org/10.4996/fireecology.0601036.

McBratney, A.B., M.L.M. Santos, and B. Minasny. 2003. On digital soil mapping. Geoderma 117: 3-52 https://doi.org/10.1016/S0016-7061(03)00223-4.

McWethy, D.B., P.E. Higuera, C. Whitlock, T.T. Veblen, D.M.J.S. Bowman, G.J. Cary, S. G. Haberle, R.E. Keane, B.D. Maxwell, M.S. McGlone, G.L.W. Perry, J.M. Wilmshurst, A. Holz, and A.J. Tepley. 2013. A conceptual framework for predicting temperate ecosystem sensitivity to human impacts on fire regimes. Global Ecology and Biogeography 22: 900-912 https://doi.org/10. 1111/geb.12038.

Miller, M.E., W.J. Elliot, M. Billmire, P.R. Robichaud, and K.A. Endsley. 2016. Rapidresponse tools and datasets for post-fire remediation: Linking remote sensing and process-based hydrological models. International Journal of Wildland Fire 25: 1061-1073 https://doi.org/10.1071/WF15162.

Moody, J.A., R.A. Shakesby, P.R. Robichaud, S.H. Cannon, and D.A. Martin. 2013. Current research issues related to post-wildfire runoff and erosion processes. Earth-Science Reviews 122: 10-37 https://doi.org/10.1016/j.earscirev.2013.03. 004.

Moseley, K., P.L. Shaver, H. Sanchez, and B.T. Bestelmeyer. 2010. Ecological site development: A gentle introduction. Rangelands 32: 16-22 https://doi.org/10. 2111/RANGELANDS-D-10-00087.1.

Nauman, T.W., and M.C. Duniway. 2016. The automated reference toolset: A soilgeomorphic ecological potential matching algorithm. Soil Science Society of America Journal 80: 1317-1328 https://doi.org/10.2136/sssaj2016.05.0151.

Nauman, T.W., M.C. Duniway, M.L. Villarreal, and T.B. Poitras. 2017. Disturbance automated reference toolset (DART): Assessing patterns in ecological recovery from energy development on the Colorado plateau. The Science of the Total Environment 584: 476-488 https://doi.org/10.1016/j.scitotenv.2017.01.034.

NIFC [National Interagency Fire Center]. 2018. Wildland fire statistics. <http:// www.nifc.gov/firelnfo/firelnfo_statistics.html>. Accessed 6 Apr 2018.

NRCS [Natural Resources Conservation Service]. 2018. Digital Soil Mapping (DSM). <https://www.nrcs.usda.gov/wps/portal/nrcs/detail/soils/survey/geo/?cid= stelprdb1254424>. Accessed 4 Sept 2018.

Ochsner, T.E., M.H. Cosh, R.H. Cuenca, W.A. Dorigo, C.S. Draper, Y. Hagimoto, Y.H. Kerr, E.G. Njoku, E.E. Small, M. Zreda, and K.M. Larson. 2013. State of the art in large-scale soil moisture monitoring. Soil Science Society of America Journal 77: 1888-1919 https://doi.org/10.2136/sssaj2013.03.0093.

Parks, S.A., M.-A. Parisien, and C. Miller. 2012. Spatial bottom-up controls on fire likelihood vary across western North America. Ecosphere 3: art12 https://doi. org/10.1890/ES11-00298.1.

Parsons, A., P.R. Robichaud, S.A. Lewis, C. Napper, and J.T. Clark. 2010. Field guide for mapping post-fire soil burn severity. USDA Forest Service general technical report RMRS-GTR-243. Fort Collins: Rocky Mountain Research Station https:// doi.org/10.2737/RMRS-GTR-243.

Qi, Y., P.E. Dennison, J. Spencer, and D. Riano. 2012. Monitoring live fuel moisture using soil moisture and remote sensing proxies. Fire Ecology 8: 71-87 https:// doi.org/10.4996/fireecology.0803071.

Quiring, S.M., T.W. Ford, J.K. Wang, A. Khong, E. Harris, T. Lindgren, D.W. Goldberg, and Z. Li. 2016. The north American soil moisture database: Development and applications. Bulletin of the American Meteorological Society 97: 14411459 https://doi.org/10.1175/bams-d-13-00263.1.

Ramcharan, A., T. Hengl, T. Nauman, C. Brungard, S. Waltman, S. Wills, and J. Thompson. 2018. Soil property and class maps of the conterminous United States at 100-meter spatial resolution. Soil Science Society of America Journal 82: 186-201 https://doi.org/10.2136/sssaj2017.04.0122.

Rangeland Fire Task Force. 2015. An integrated rangeland fire management strategy final report to the secretary of the interior. <https://www. forestsandrangelands.gov/documents/rangeland/ IntegratedRangelandFireManagementStrategy_FinalReportMay2015.pdf>. Accessed 31 Aug 2017.

Reeves, M.C., and J.E. Mitchell. 2011. Extent of coterminous US rangelands: Quantifying implications of differing agency perspectives. Rangeland Ecology \& Management 64: 585-597 https://doi.org/10.2111/REM-D-11-00035.1. 
Renschler, C. 2003. Designing geospatial interfaces to scale process models: The GeoWEPP approach. Hydrological Processes 17: 1005-1017 https://doi.org/10. 1002/hyp.1177.

Robichaud, P., W. Elliot, F. Pierson, D. Hall, and C. Moffet. 2007. Predicting post-fire erosion and mitigation effectiveness with a web-based probabilistic erosion model. Catena 71: 229-241 https://doi.org/10.1016/j.catena.2007.03.003.

Sankey, J.B., M.J. Germino, T.T. Sankey, and A.N. Hoover. 2012a. Fire effects on the spatial patterning of soil properties in sagebrush steppe, USA: A metaanalysis. International Journal of Wildland Fire 21: 545-556 https://doi.org/10. 1071/wf11092.

Sankey, J.B., S. Ravi, C.S.A. Wallace, R.H. Webb, and T.E. Huxman. 2012b. Quantifying soil surface change in degraded drylands: Shrub encroachment and effects of fire and vegetation removal in a desert grassland. Journal of Geophysical Research - Biogeosciences 117: G02025 https://doi.org/10.1029/ 2012jg002002.

Scull, P., J. Franklin, O.A. Chadwick, and D. McArthur. 2003. Predictive soil mapping: A review. Progress in Physical Geography 27: 171-197 https://doi. org/10.1191/0309133303pp366ra.

Smith, R.J., S.R. Abella, and L.R. Stark. 2014. Post-fire recovery of desert bryophyte communities: Effects of fires and propagule soil banks. Journal of Vegetation Science 25: 447-456 https://doi.org/10.1111/jvs.12094.

Soil Science Division Staff. 2017. Soil survey manual. In USDA Handbook 18, ed. C. Ditzler, K. Scheffe, and H.C. Monger. Washington, D.C.: Government Printing Office.

Soil Survey Staff (2018a) Natural Resources Conservation Service, United States Department of Agriculture. Gridded soil survey geographic (gSSURGO) database for the conterminous United States. <https://gdg.sc.egov.usda.gov/ $>$. Accessed 4 July 2018

Soil Survey Staff (2018b) Natural Resources Conservation Service, United States Department of Agriculture. Soil survey geographic database (SSURGO). $<$ https://gdg.sc.egov.usda.gov/>. Accessed 4 July 2018.

Soil Survey Staff (2018c) Natural Resources Conservation Service, United States Department of Agriculture. US general soil map (STATSGO2). <https://gdg.sc. egov.usda.gov/>. Accessed 4 July 2018

Stephan, K., M. Miller, and M.B. Dickinson. 2010. First-order fire effects on herbs and shrubs: Present knowledge and process modeling needs. Fire Ecology 6: 95-114 https://doi.org/10.4996/fireecology.0601095.

Stoof, C.R., D. Moore, P.M. Fernandes, J.J. Stoorvogel, R.E.S. Fernandes, A.J.D. Ferreira, and C.J. Ritsema. 2013. Hot fire, cool soil. Geophysical Research Letters 40: 1534-1539 https://doi.org/10.1002/grl.50299.

Stringham, T.K., P. Novak-Echenique, D.K. Snyder, S. Peterson, and K.A Snyder. 2016. Disturbance response grouping of ecological sites increases utility of ecological sites and state-and-transition models for landscape scale planning in the Great Basin. Rangelands 38: 371-378 https://doi.org/10.1016/j.rala.2016.10.006.

Sturtevant, B.R., and D.T. Cleland. 2007. Human and biophysical factors influencing modern fire disturbance in northern Wisconsin. International Journal of Wildland Fire 16: 398-413 https://doi.org/10.1071/wf06023.

US National Park Service. 2006. Interagency burned area emergency response guidebook. <www.nps.gov/archeology/npsGuide/fire/docs/ 18\%20Interagency\%20BAER\%20Handbook.pdf >. Accessed 23 Nov 2018.

van der Werf, G.R., J.T. Randerson, L. Giglio, T.T. van Leeuwen, Y. Chen, B.M. Rogers, M. Mu, M.J.E. van Marle, D.C. Morton, G.J. Collatz, R.J. Yokelson, and P. S. Kasibhatla. 2017. Global fire emissions estimates during 1997-2015. Earth System Science Data 9: 697-720 https://doi.org/10.5194/essd-2016-62.

Waring, R.H., and N.C. Coops. 2016. Predicting large wildfires across western North America by modeling seasonal variation in soil water balance. Climatic Change 135: 325-339 https://doi.org/10.1007/s10584-015-1569-x.

Whitman, E., E. Batllori, M.-A. Parisien, C. Miller, J.D. Coop, M.A. Krawchuk, G.W. Chong, and S.L. Haire. 2015. The climate space of fire regimes in NorthWestern North America. Journal of Biogeography 42: 1736-1749 https://doi. org/10.1111/jbi.12533.

Wieder, W.R., J. Boehnert, G.B. Bonan, and M. Langseth. 2014. Regridded harmonized world soil database v1.2. Oak Ridge: Oak Ridge National Laboratory Distributed Active Archive Center https://doi.org/10.3334/ ornldaac/1247. Accessed 31 Aug 2017.
Williams, C.J., F.B. Pierson, P.R. Robichaud, and J. Boll. 2014. Hydrologic and erosion responses to wildfire along the rangeland-xeric forest continuum in the western US: A review and model of hydrologic vulnerability. International Journal of Wildland Fire 23: 155-172 https://doi.org/10.1071/wf12161.

Yang, J., P.J. Weisberg, T.E. Dilts, E.L. Loudermilk, R.M. Scheller, A. Stanton, and C. Skinner. 2015. Predicting wildfire occurrence distribution with spatial point process models and its uncertainty assessment: A case study in the Lake Tahoe Basin, USA. International Journal of Wildland Fire 24: 380-390 https:// doi.org/10.1071/WF14001.

\section{Submit your manuscript to a SpringerOpen ${ }^{\circ}$ journal and benefit from:}

- Convenient online submission

- Rigorous peer review

- Open access: articles freely available online

- High visibility within the field

- Retaining the copyright to your article

Submit your next manuscript at $\boldsymbol{\sim}$ springeropen.com 